\title{
TREE REGENERATION IN SACRED GROVES OF KATHMANDU VALLEY, NEPAL
}

\author{
L.J. Shrestha ${ }^{1 *}$, M.P. Devkota ${ }^{1}$ and B.K. Sharma ${ }^{2}$ \\ ${ }^{1}$ Botany Department, Amrit Campus \\ Institute of Science and Technology, Tribhuvan University, Kathmandu \\ ${ }^{2}$ Green Governance Nepal, Kathmandu \\ *Email: joshi.laxmi.shrestha@gmail.com
}

\begin{abstract}
Population structure and regeneration status of tree species were studied in two sacred groves of Kathmandu valley, Pashupati (PSG) and Bajrabarahi (BSG) by sampling in concentric circular plots of $20 \mathrm{~m}$ radius. The dominant tree species of PSG are Schima wallichii, Pyrus pashia, Myrsine capitellata, Persea odoratissima and Quercus glauca, where as those in BSG are Neolitsea cuipala, Castanopsis indica, Choerospondias axillaris, Schima wallichii and, Myrsine capitellata. On the basis of biomass removal, tree cutting, livestock and wildlife grazing and other anthropogenic activities, disturbance levels were classified as undisturbed, least disturbed, moderately disturbed and highly disturbed. The highest number of seedlings, saplings and adults were found in the least disturbed areas of the studied groves showing good to fair regeneration of tree species. In this study Pyrus pashia, Myrsine capitellata, Castanopsis indica, Neolitsea cuipala are found in good and fair state of regeneration. Management authority should address the prevalent factors affecting natural regeneration of the tree species.
\end{abstract}

Key words: Importance value index, disturbance index, sapling, seedling.

\section{INTRODUCTION}

A tract of virgin forest with rich biodiversity that has been traditionally managed by the local community based on the ground of indigenous cultural and religious beliefs, and taboos is considered as scared groves (Khumbongmayum et al. 2006). The groves are a universal human phenomenon not associated with any specific religion or worldview, but have a strong religious perspective and are influenced by traditional local beliefs. Sacred groves have significant effects on environment conservation due to the special precautions and exclusion from social fencing - a management by local communities applying their religious faith and belief - associated with them (Singh 2012). With limited human activity due to taboos and prohibition of resource utilization, sacred groves frequently possess old growth vegetation, integrated nutrient cycling with high soil fertility, and many ecologically and socially valuable biotic species (Ramakrishnan 1996, Godbole and Sarnaik 2004). Sacred groves function as natural gene pool reserve and set an example of environment conservation by 
community participation (Gadgil and Vartak 1975) to ensure benefits to human societies in various ways.

Different growth forms of woody plant species is the main constituent for the formation of community structures of forest and the ecological characteristics of sites, species diversity and regeneration status (Khumbongmayum et al. 2006). Growth stages of trees in the plant community are affected by micro-environmental conditions and help to maintain the population structure of the forest. Hence, the population structure of a species in forest community can express its regeneration behavior (Saxena and Singh 1984). The population structure characterized by the presence of sufficient number of seedlings, saplings and adults indicates successful regeneration of forest species (Saxena and Singh 1984). Regeneration status of tree species depends on the maturity and diameter structure of their population (Bhuyan et al. 2003). Characteristics of the forest floor, microenvironmental conditions under the forest canopy and anthropogenic activities influence the regeneration status of trees (Mishra et al. 2003).

An increased availability of light stimulates germination of seeds in several forest trees and inhibits it in a few. The tree fall gaps cause increase in seedling recruitment and establishment of seedlings as well as saplings. Growth of seedlings is often limited by the availability of soil nutrients, especially N and P (Mishra et al. 2003).

The study of regeneration of forest trees has important implications for the biodiversity conservation and forest management. Sacred groves are hailed as models of community based conservation and storehouse of valuable biodiversity. Their importance to forest conservation from community based model becomes even more significant in Nepal. The main criterions used for the study area selection are size of the sacred groves, their location, legality and duration of the forest management practices from the local community. Based on the mentioned criterion two sites Pashupati (government managed) and Bajrabari (community managed) were selected to evaluate the management system. This study attempts to understand the population structure and regeneration status of tree species in those sacred groves of Kathmandu valley.

\section{STUDY AREA}

The study was conducted during 2012-2013 in two sacred groves of Kathmandu valley from the midhil physiographic zone of Central Development Region of Nepal (Map 1). Pashupati is one of the important pilgrimage site of Hindu called as Pashupati Sacred Grove (PSG) that belongs to the Lord Pashupatinath temple in Kathmandu valley, the capital city of Nepal. The area was inscribed as world heritage site by UNESCO in 1979. It is located at $27^{\circ} 42^{\prime} 25^{\prime \prime}$ to $27^{\circ} 42^{\prime} 36^{\prime \prime} \mathrm{N}$ latitude and $85^{\circ} 20^{\prime} 12^{\prime \prime}$ to $85^{\circ} 21^{\prime} 29^{\prime \prime}$ E longitude at an average elevation of 1,300 $\mathrm{m}$ and covering an area of 83.55 ha. Based on historical facts it has been estimated that the grove is 1400 years old (Mansberger 1991) and has been considered as a bio-cultural landscape having close relationship with religious, socio-cultural beliefs, taboos and conservation practices. Pashupati Area Development Trust (PADT), a government organization, has undertaken management responsibility of this grove.

The other study site was Bajrabarahi Sacred Grove (BSG) located at south-east corner of Kathmandu valley, in Chapagaun of Lalitpur district. It is located at an elevation of $1440 \mathrm{~m}$ between $27^{\circ} 36^{\prime} 15.88^{\prime \prime}$ and $27^{\circ} 366^{\prime 24.62 " ~} \mathrm{~N}$ latitude and $85^{\circ} 19^{\prime} 40.58^{\prime \prime}$ and $85^{\circ} 19^{\prime} 50.59^{\prime \prime}$ E longitude with 18.29 ha area. This grove represents 900 years old (Mansberger 1991) and Jyotidaya Sangh, a community based organization is managing this forest since 1994. 


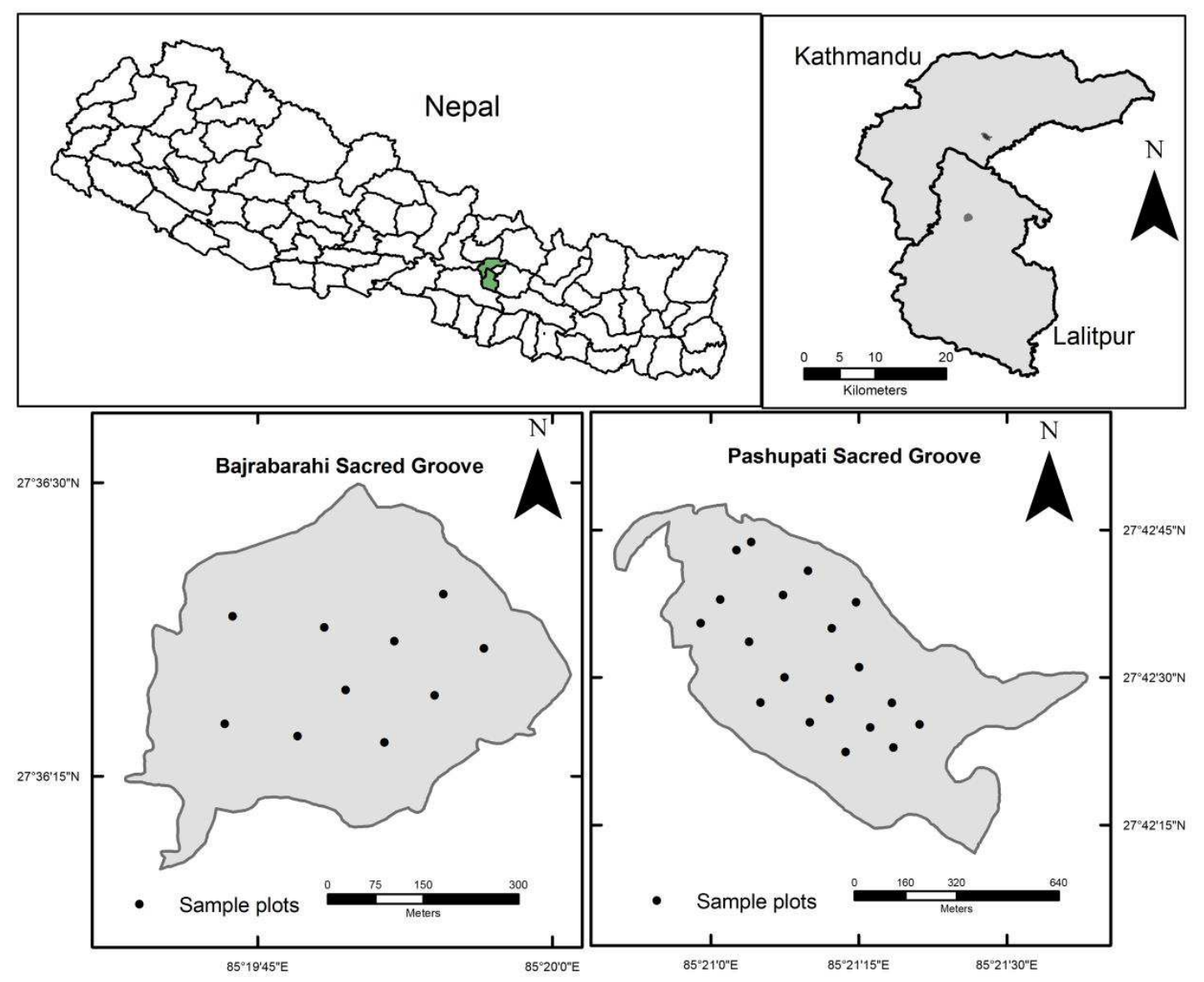

Map 1. Location of study area and distribution of surveyed plots.

\section{MATERIALS AND METHODS}

Parallel transects in the north-south directions with $150 \mathrm{~m}$ interval were laid down on which concentric circular plot at an interval of $100 \mathrm{~m}$ were set for the inventory of tree species Concentric Circular Sample Plots (CCSPs) were used to collect the field data following FRA/DFRS (2014). The central point of CCP was identified by using Geographic Position System (GPS) incorporated already identified coordinates from Google Earth images. Nineteen plots were laid down in PSG and 10 plots in BSG. The CCSP consist of four circular plots: plot with the radius of $20 \mathrm{~m}$ (area: $1257.1 \mathrm{~m}^{2}$ ) for trees with diameter at breast height $(\mathrm{DBH}) \geq 30 \mathrm{~cm}$; plot with the radius 15m (area: $707.1 \mathrm{~m}^{2}$ ) for trees with DBH 20.0 to $30.0 \mathrm{~cm}$; the third plot with the radius $8 \mathrm{~m}$ (area: $201.1 \mathrm{~m}^{2}$ ) for trees with DBH from 10.0 to 20.0 $\mathrm{cm}$; and fourth plot with the radius $4 \mathrm{~m}$ (area: 50.2 $\mathrm{m}^{2}$ ) for trees with DBH from $5.0 \mathrm{~cm}$ to $10.0 \mathrm{~cm}$. Similarly, with the help of Spherical Densiometer, percentage crown cover was measured at five points on the plot, i.e., at the plot centre and at the four cardinal directions (N, E, S and W) 20 meters apart from the plot centre. Plot wise crown cover percentages was calculated by multiplying the number of crown-covered grid points by 2.2 (FRA/DFRS 2014). The height and DBH of trees (woody plant with single bole, $>5 \mathrm{~cm} \mathrm{DBH}$ and > $1.3 \mathrm{~m}$ height) were measured with the help of 
Vertex IV with Transponder T3 and diameter tape, respectively. Data regarding the seedling and sapling were collected from four subplots with the radius of $2 \mathrm{~m}\left(12.6 \mathrm{~m}^{2}\right)$ located 10 meters from the plot center of the CCSP in four cardinal directions. Soil samples were collected from each plot to measure soil $\mathrm{pH}$ and analyze total organic matter, available Nitrogen, Potassium and Phosphorus. Soil samples were collected from five soil pits (15 $\mathrm{cm} * 15 \mathrm{~cm} * 5 \mathrm{~cm})$, one in each four cardinal directions (N, E, W and S) $20 \mathrm{~m}$ far from plot center and one in the plot center of the CCPS. The collected soil samples (200 gm from each pit) were mixed together and one $\mathrm{kg}$ of soil was packed in a polythene bag. Standard methods were used to measure soil $\mathrm{pH}$ (soil:water ratio is $1: 2$ ), organic matter content was done by volumetric method, total Nitrogen analysis by Kjeldahl method, available phosphorus by Bray and Kurt, available potassium by flame photometer method and soil texture by hydrometer method (Bouyoucos 1962). The analysis of soil was done in soil science laboratory of Nepal Agricultural Research Council, Lalitpur, Nepal. The analyzed soil nutrients were classified in to five categories: very low, low, medium, high and very high (GoN 2010).

The density (number per ha) of saplings and seedlings were considered as the indicator of regeneration status of each dominant tree species in each grove. Regeneration status of tree species was analyzed on the basis of population size of seedlings and sapling following Shankar (2001) and Khumbongmayum et al. (2006) in the following categories: (a) good: if seedling > sapling > adult; (b) fair: if seedling > sapling $\leq$ adult; (c) poor: if a species survives in only sapling stage, but not as seedling (though saplings may be less, more or equal to adults), (d) none: if a species is absent both in sapling and seedling stages, but present as adults; and (e) new: if a species has no adults, but only saplings and/or seedlings. Species importance value was used to classify the existing forests in the study area (Sharma et al. 2012, Shrestha et al. 2014).

To assess the disturbances physical conditions of every tallied tree individual within CCSPs were noted. The disturbances of living trees were categorized as healthy, partly broken at the top or partly dry. The disturbances of dead trees included standing dead, completely dry, and fallen (green or dry). The anthropogenic disturbances of tree and vegetation in each CCSP were assessed by counting the individual tree which was lopped, logged, cut or burnt. Besides the disturbance on vegetation, other disturbances like erosion, access track, drain, rubbish dumping, picnic spot, permanent structure, cemetery, grazing (livestock and wildlife), litter collection, fencing, access road within each CCSP were also assessed.

On the basis of biomass removal, tree cutting, livestock and wildlife grazing and other anthropogenic activities disturbance levels were classified in four categories like undisturbed, least disturbed, moderately disturbed and highly disturbed. The degree of disturbance was measured through a disturbance index (DI) based on the percent number of cut, dead or damaged of individual trees in the plant communities. A DI value of 60 was taken as the lower limit of high disturbance and a value of 30 as the upper limit of low disturbances (Pandey and Shukla 2001). Paired $t$-tests were used to compare soil parameters with tree regeneration and drivers of deforestation with tree regeneration (Johnson and Bhattacharya 1996).

\section{RESULTS}

The study sites belongs to Schima-Castanopsis forest (Stainton 1972) of subtropical climatic region of mid-hill physiographic region Nepal (Sharma 2014). However, some vegetation of these sites have been changed to its secondary forms. On the basis of importance value of trees three types of forest were identified from PSG and only one 
from BSG. The forest types of PSG were SchimaPyrus, Myrsine-Persea and Quercus-Myrsine and that of BSG was Neolitsea cuipala (Shrestha et al. 2014). The average canopy cover of PSG was $55 \%$ and that of BSG was $90.8 \%$.

The identified anthropogenic disturbances in PSG were freshly cut trees, dead or rotten trees, coppice re-growth, erosion, access track, rubbish dumping, picnic spot, cemetery, sport activities (badminton court), livestock and wildlife grazing, water point, earth work, fence lines, construction of permanent structures like buildings as well as army camp (Fig. 1a). In PSG $42 \%$ area were least disturbed, $37 \%$ were highly disturbed and $21 \%$ were moderately disturbed.

In the least disturbed areas of PSG, numbers of seedlings were 2089 individual ha ${ }^{-1}$, saplings were 298 individuals $\mathrm{ha}^{-1}$ and adult trees were 240 individuals $\mathrm{ha}^{-1}$, which showed good regeneration status. In moderately disturbed plots the numbers of seedlings were 398 individuals $\mathrm{ha}^{-1}$, saplings were 311 individuals $\mathrm{ha}^{-1}$ and adults were 227 individuals $\mathrm{ha}^{-1}$, which showed good regeneration. In highly disturbed plots the numbers of seedlings were 28 individuals $\mathrm{ha}^{-1}$, saplings were 169 individuals ha $^{-1}$ and adults were 212 individuals ha 1 , with poor regeneration status (Table 1). In the study area there was significant effect of disturbances in tree regeneration $(\mathrm{t}=1.82, p<0.05$, $\mathrm{df}=18)$.

In PSG the seedling density was greater than that of the sapling and tree and there were equal number of saplings and trees individuals per hectare. So, the status of tree regeneration in Pashupati sacred grove was good (Table 1). Out of 23 (Table 5) tree species recorded in PSG, number of species (23) is greater in seedling level and few (17 species) in tree level. The regeneration of two species, namely Myrsine capitellata and Pyrus pashia was found good, seven species of trees were fairly regenerating, three species of trees were poorly regenerating, three species of trees were not regenerating and eight species trees were newly arising at seedling and sapling stages (Table $3)$. The regeneration status of the tree was good in Schima-Pyrus forest. There was fair regeneration of tree species in Myrsine-Persea and QuercusMyrsine forests of PSG.

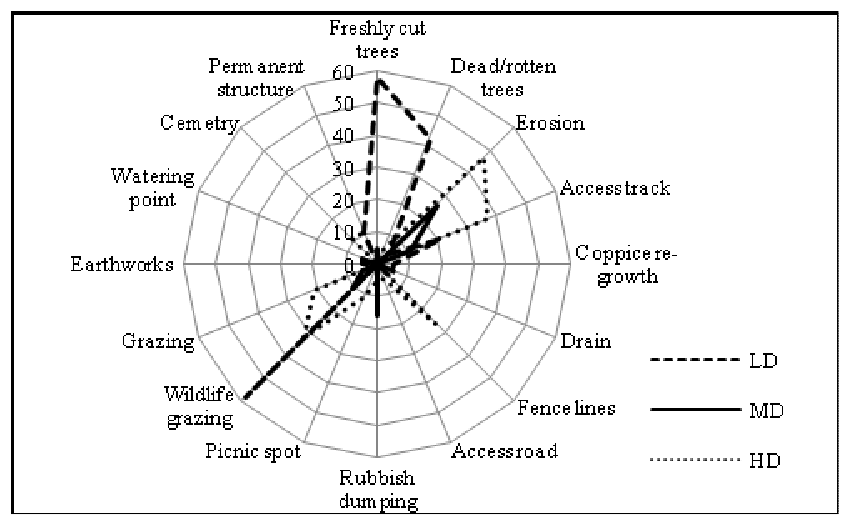

(a)

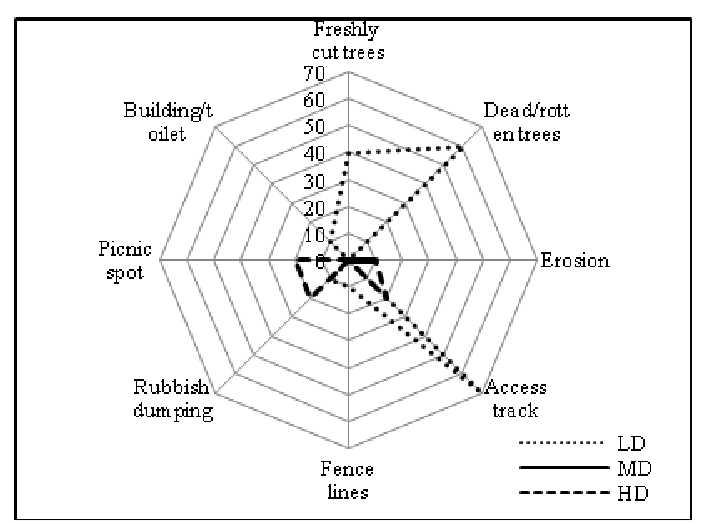

(b)

Fig. 1. Types of disturbances and their intensity in PSG (a) and BSG (b). (LD-least disturbed, MD-moderately disturbed, HD-highly disturbed) 
Table 1. Regeneration status of forest in PSG.

\begin{tabular}{lcccc}
\hline Disturbance Status & Seedling ha $^{-\mathbf{1}}$ & Sapling ha $^{\mathbf{- 1}}$ & Tree ha $^{\mathbf{- 1}}$ & Regeneration status $^{\text {Least disturbed }}$ \\
Moderately disturbed & 2089 & 298 & 240 & Good \\
Highly disturbed & 398 & 311 & 237 & Good \\
\hline
\end{tabular}

Table 2. Soil characteristics of PSG and BSG.

\begin{tabular}{lcc}
\hline Soil characters & Sacred Grove \\
& PSG & BSG \\
\hline $\mathrm{pH}$ & 4.70 & 4.20 \\
Nitrogen $(\%)$ & 0.15 & 0.11 \\
Organic matters (\%) & 3.70 & 2.54 \\
Potassium $\left(\mathrm{kg} \mathrm{ha}^{-1}\right)$ & 902.00 & 617.07 \\
Phosphorus $\left(\mathrm{kg} \mathrm{ha}^{-1}\right)$ & 348.00 & 168.87 \\
\hline
\end{tabular}

Table 3. Regeneration status of forest in BSG.

\begin{tabular}{lcccc}
\hline Disturbance Status & Seedling ha $^{-1}$ & Sapling ha $^{-1}$ & Tree ha $^{-1}$ & Regeneration status \\
\hline Undisturbed & 3981 & 0 & 430 & Fair \\
Least disturbed & 1558 & 17 & 409 & Fair \\
Moderately disturbed & 0 & 199 & 263 & Poor \\
Highly disturbed & 0 & 0 & 462 & None \\
\hline
\end{tabular}

Different types of anthropogenic and natural disturbances were recorded from the forest areas of BSG. They were freshly cut trees, dead or rotten trees, soil erosion, access track, rubbish dumping, picnic spot, fence lines, and construction of permanent structures like buildings and toilets (Fig. 1b).

The study revealed that $10 \%$ of the study area were undisturbed, $10 \%$ were moderately disturbed $20 \%$ were highly disturbed, and $60 \%$ were least disturbed. The highest number of seedlings $(3,981$ $\left.\mathrm{ha}^{-1}\right)$ and adult trees $\left(430 \mathrm{ha}^{-1}\right)$ were recorded from the undisturbed forest areas. The sapling stage of tree were absent in these areas and indicated the fair regeneration status. In least disturbed areas, the recorded numbers of seedlings were $1558 \mathrm{ha}^{-1}$, saplings were $17 \mathrm{ha}^{-1}$ and trees were $409 \mathrm{ha}^{-1}$ with fair regeneration status. In the moderately disturbed forest seedlings were absent (Table 3) numbers of saplings were $199 \mathrm{ha}^{-1}$ and the numbers of adult trees were found $263 \mathrm{ha}^{-1}$ with poor status of regeneration. In highly disturbed forest areas the seedlings and sapling stage of tree were absent and the numbers of adults were $462 \mathrm{ha}^{-1}$ which showed no regeneration status. There was significant effect of disturbances in tree regeneration $(\mathrm{t}=2.80$, $p<0.05$, df $=9$ ).

The regeneration status of available tree species in Bajrabarahi sacred grove was fair. Out of 19 recorded tree species from BSG (Table 5), $26.3 \%$ tree species showed fair regeneration, $68.4 \%$ trees were not regenerating and a new species, Boehmeria rugulosa was regenerating in seedling stage. In this forest the most dominant tree species Neolitsea cuipala, Castanopsis tribuloides, and Castanopsis indica including other two tree species, Albizia lebbeck and Celtis australis, showed fair regeneration. The sapling stage of these tree species was absent. In BSG Castanopsis tribuloides had good population of seedlings, but these were not maturing enough as saplings and adult stages. Thirteen tree species were not regenerating in BSG (Table 4).

ECOPRINT VOL 22, 2015 
Table 4. Regeneration status of tree species in study area.

\begin{tabular}{lcc}
\hline Regeneration status & \multicolumn{2}{c}{ Number of species } \\
& PSG & BSG \\
\hline Fair & 7 & 5 \\
Good & 2 & 0 \\
New & 8 & 1 \\
None & 3 & 13 \\
Poor & 3 & 0 \\
Total & 23 & 19 \\
\hline
\end{tabular}

The average $\mathrm{pH}$ found in the soil of BSG was acidic (4.2). The average level of nitrogen content found in the BSG was $0.11 \%$ which was in medium range. There was significant effect of Nitrogen in tree regeneration of BSG $(\mathrm{t}=2.80$, $p<0.05$, $\mathrm{df}=9$ ). The average level of phosphorus content recorded in the soil of BSG was $168.87 \mathrm{~kg}$ $\mathrm{ha}^{-1}$ which in very high range. There was significant effect of Phosphorus in tree regeneration in BSG $(\mathrm{t}=2.45, p<0.05, \mathrm{df}=9)$. The average level of potassium content recorded in the soil of BSG was 617.07 which was in very high range. There was no significant effect of Potassium in tree regeneration of $\mathrm{BSG}(\mathrm{t}=1.52, p<0.05, \mathrm{df}=$ $9)$. The average level of organic matters content found in the soil of BSG was $2.54 \%$ was in medium range (Table 2). There was significant effect of organic matters in tree regeneration of BSG $(\mathrm{t}=2.79, p<0.05$, df $=9)$.

Table 5. Tree species and their regeneration status.

\begin{tabular}{|c|c|c|c|c|}
\hline \multirow[t]{2}{*}{$\mathbf{S N}$} & \multirow[t]{2}{*}{ Tree species } & \multirow[t]{2}{*}{ Family } & \multicolumn{2}{|c|}{ Regeneration status } \\
\hline & & & PSG & BSG \\
\hline 1 & Choreospondias axilaris (Roxb.) B.L. Brutt. and A.W. Hill. & Anacardiaceae & Poor & None \\
\hline 2 & Rhus succedanea $\mathrm{L}$. & Anacardiaceae & - & None \\
\hline 3 & Araucaria bidwill Hook. & Araucariaceae & None & - \\
\hline 4 & Alnus nepalensis D. Don & Betulaceae & New & - \\
\hline 5 & Betula alnoidesBuch.-Ham. ex D. Don & Betulaceae & New & - \\
\hline 6 & Sapium insigne (Royle) Benth. ex. Hook.f & Eurphorbiaceae & - & None \\
\hline 7 & Castonopsis indica (Roxb.) Miq & Fagaceae & - & Fair \\
\hline 8 & Castanopsis tribuloides (Sm.) A. DC. & Fagaceae & None & Fair \\
\hline 9 & Quercus glauca Thunb. & Fagaceae & Fair & - \\
\hline 10 & Juglans regia $\mathrm{L}$. & Juglandaceae & New & - \\
\hline 11 & Litsea lanciffolia (Roxb.ex Nees) Hook.f & Lauraceae & New & - \\
\hline 12 & Neolitsea cuipala (Buch.-Ham. ex D. Don) Kosterm. & Lauraceae & - & Fair \\
\hline 13 & Persea odoratissima (Nees) Kosterm. & Lauraceae & Fair & None \\
\hline 14 & Albizia julibrissin Durazz. & Leguminosae & - & None \\
\hline 15 & Albizia lebbeck (L.) Benth. & Leguminosae & - & Fair \\
\hline 16 & Cassia fistula $\mathrm{L}$ & Leguminosae & - & None \\
\hline 17 & Morus alba & Moraceae & New & - \\
\hline 18 & Myrica esculenta Buch.-Ham. Ex D. Don & Myricaceae & None & None \\
\hline 19 & Myrsine capitellata Wall. & Myrsinaceae & Good & None \\
\hline 20 & Myrsine semiserrata Wall. & Myrsinaceae & Poor & None \\
\hline 21 & Syzygium cumini (L.) Skeels. & Myrtaceac & Fair & None \\
\hline 22 & Fraxinus floribunda Wall. & Oleaceae & New & - \\
\hline 23 & Areca catechu $\mathrm{L}$. & Palmae & - & None \\
\hline 24 & Zizyphus incurva Roxb. & Rhamnaceae & Poor & - \\
\hline 25 & Prunus cerasoides D. Don & Rosaceae & New & - \\
\hline
\end{tabular}

ECOPRINT VOL 22, 2015 


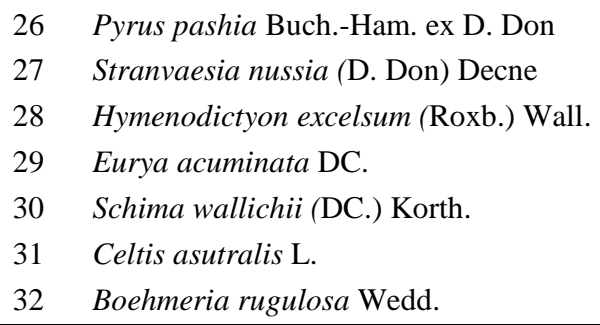

\section{DISCUSSIONS}

The regeneration status of tree species in the study area were recognized as good (PSG) and fair (BSG). This study has identified that the density of seedling, sapling and adult was found higher in least disturbed forest stand than moderately disturbed stand and no regeneration in highly disturbed forest stand. It has also reported that higher numbers of adult trees were available in undisturbed and were found least in disturbed forest stands.

Stem density was found higher in the open canopy forest with less anthropogenic activities where greater density of seedling than the adult trees. This finding favor the general ecological principle that the open canopy forest with less anthropogenic disturbances favor plant regeneration. Open canopy of the forest provide sufficient light in the forest floor and is useful for the plant regeneration. Thus, there is possibilities to regenerate new plant species which ultimately effect on species richness of the particular area. A similar kind of study conducted in the wet evergreen Dipteracarpus forests of Assam Valley, tropical evergreen forest of Arunachal Pradesh, India (Bhuyan et al. 2002), Uttara Khanda and Western Ghats of India (Murthy et al. 2002) provided the similar findings about the regeneration of tree species. The study conducted in Garhwal Himalaya of India also identified higher numbers of adult trees density in undisturbed and least disturbed stand (Uniyal et al. 2010). Another study conducted in Manipur of
India, identified highest stand density and species richness in the lowest girth class $(30-60 \mathrm{~cm})$ and decreased in the succeeding girth classes (Khumbongmayum et al. 2006). A study conducted in tropical forest in Garo Hills of Northeast India identified that primary forests were more tree-rich and diverse than secondary forests or Sal plantations (Kumar et al. 2006).

During the study tree cutting, lopping, fire, erosion, access track and roads, fence lines, high tension lines, rubbish dumping, picnic spot, wildlife and livestock grazing; litter collection, earthworks, and permanent structures were directly observed as major drivers of deforestation and forest degradation. In the studied groves, forest areas were either replaced or fragmented due to road and trail construction (PSG) and construction of picnic spots (BSG) to attract tourists. Both sacred groves have a large influx of people, from all over the country and neighboring India. The number of visitor will be higher during religious festivals like Maha Shivaratri, Teej, Bala Chaturdashi and Janai Purnima in PSG and various local festivals (Jatras) in BSG. Both groves also offer both religious spots and open place for city dwellers and offer large number visitors during holidays. Being a UNESCO's World Heritage Site, PSG is also an attraction for international visitors to observe Hindu rituals. Local traditions and customs have been challenged by westernized urban cultures learned from large number of tourist visiting the area. Modern education system has also failed to respect the local traditions and 
customs. As a result, sacred groves have been losing its cultural importance for the younger generation of local people.

The Pashupati Sacred Grove is fragmented by road construction leading to loss of species composition and interruption in ecological function. The forest areas of PSG were also found encroached from government line agencies for the extension of International Airport and construction of religious permanent structures. These drivers of deforestation recorded in current study areas resembled with the study conducted in the sacred groves of Karnataka, India. In Karnataka the recorded threats for the conservation of sacred groves were development projects, commercial forestry, and shift in belief system, sanskritilisation, pilgrimage and tourism, removal of biomass, encroachment, modernization and market forces, and fragmentation and perforation (Gokhale 2005). The study conducted in sacred groves of Jammu, India, also identified similar types of threats, namely construction activities, livestock grazing, and modernization for the long term conservation of sacred groves (Sharma and Devi 2014).

\section{CONCLUSION}

The population structure of tree species showed seedling populations dominate tree populations and which provided good to fair regeneration status. Presence of new species in the groves may be due to the invasion through dispersal from other areas and the prevailing favorable micro environmental conditions contributed to their establishment and growth in the groves. Richness of tree species and stand density were found higher in open canopy forest with no anthropogenic disturbances. Management authority should be aware to address the prevalent factors affecting natural regeneration of the tree species.

\section{ACKNOWLEDGEMENTS}

The study was supported by University Grants Commission of Nepal under the Ph.D. support program. We are thankful to Pashupati Area Development Trust and Jyotidaya Sangh Bajrabarahi for their encouraging support to carry out research in respective sacred groves. Forest Resource Assessment Nepal is acknowledged for providing survey equipment. We would like to thank Ms Babita Shrestha and Ms Rajol Shrestha for helping us during the field works and we are also thankful to Mr. K Bhusal for preparing the map.

\section{REFERENCES}

Bhuyan, P., M.L. Khan and R.S. Tripathi. 2002. Regeneration status and population structure of Rudraksh (Elaeocarpus ganitrus) in relation to cultural disturbances in tropical wet evergreen forest of Arunachal Pradesh, India, Current Science 83(11):1391-1394.

Bhuyan, P., M.L. Khan and R.S. Tripathi. 2003. Tree diversity and population structure in undisturbed and human- impacted stands of tropical wet evergreen forest in Arunachal Pradesh, Eastern Himalayas India, Biodiversity and Conservation 12(8): 1753-1773.

Bouyoucos, G.J. 1962. Hydrometer method improved for making particle size analysis of soils. Agron. J. 54:464-465.

FRA/DFRS. 2014. Terai Forests of Nepal (20102012). Forest Resource Assessment Nepal Project/Department of Forest Research and Survey, Babarmahal, Kathmandu.

Gadgil, M. and V.D. Vartak. 1975. Sacred groves of India - a plea for continued conservation. Journal of Bombay Natural History Society 73:314-320.

Godbole, A. and J. Sarnaik. 2004. Tradition of Sacred Groves and Communities Contribution in Their Conservation. Applied Environmental Research Foundation, Pune, pp. 60.

Gokhale, Y. 2005. Sacred groves as biocultural heritage in Karnataka, India. In: People and 
Protected Areas in South Asia. (eds.) U.R. Sharma and P.B. Yonzon. IUCN World Commission on Protected Areas, South Asia and Resources Himalaya Foundation, Kathmandu, pp. 20-26.

GoN. 2010. Procedure for Soil Sample Collection and Analysis (Mato Bishleshanko Udeshya Tatha Bishleshanko Lagi Namuna Line Tarika) - in Nepali. National Agricultural Research Council, Soil Science Division, Nepal, pp. 8-9.

Johnson, R.A. and G.K. Bhattacharyya. 1996. Statistics: Principles and Methods. John Wiley and Sons, New York, USA.

Khumbongmayum, A.D., M.L. Khan and R.S. Tripathi. 2006. Biodiversity conservation in sacred groves of Manipur, Northeast India, population structure and regeneration status of woody species. Biodiversity and Conservation 15:2439-2456.

Kumar, A., B.G. Markot and A. Saxena. 2006. Tree species diversity and distribution patterns in tropical forests of Garo Hills. Current Science 91(10): 1370-1381.

Mishra, B.P., R.S. Tripathi, O.P. Tripathi and H.N. Pandey. 2003. Effect of disturbance on the regeneration of four dominant and economically important woody species in a broadleaved subtropical humid forest of Meghalaya, Northeast India. Current Science 84:1449-1453.

Murthy, I.K., K.S. Murali, G.T. Hegde, P.R. Bhat and N.H. Ravindranath. 2002. A comparative analysis of regeneration in natural forests and joint forest management plantations in Uttara Kannada district, Western Ghats. Current Science 83(11): 1358-1364.

Pandey, S.K. and R.P. Sukla. 2001. Regeneration strategy and plant diversity status in degraded salforests. Current Science 81(1):95-102.
Ramakrishnan, P.S. 1996. Conserving the sacred: from species to landscapes. Nature and Resources, UNESCO, 32:11-19.

Saxena, A.K. and J.S. Singh. 1984. Tree population structure of certain Himalayan forest associations and implications concerning their future composition. Vegetatio 58:61-69.

Shankar, U. 2001. A case of high tree diversity in a Sal (Shorearobusta) dominated lowland forest of Eastern Himalaya: Floristic composition, regeneration and conservation. Current Science 81(7): 776-786.

Sharma B.K., M.K. Chalise and G.S. Solanki. 2012. Vegetation types and wildlife occurrence in Baghmara Buffer Zone Community Forest, Nepal. International Multidisciplinary Research Journal 2(2):5265.

Sharma, S. and R. Devi. 2014. Sacred groves: Traditional way of conserving plant diversity in block bhalwal of Jammu District (JandK). International Journal of Science and Research 3(2):239-243.

Shrestha L.J., M. Devkota and B.K. Sharma. 2014. Phyto-sociological assessment of sacred groves in Kathmandu, Nepal. International Journal of Plant and Soil Science 4(5):437444.

Singh, K.B. 2012. Sacred grove of Umangali: Indigenous means of ecological management in Manipur. In: Proceedings of National Seminar on Environment, Biodiversity and Veda and Traditional Systems. Department of Zoology, Mizorum University, India, pp. 39.

Uniyal, P., P. Pokhriyal, S. Dasgupta, D. Bhatt. and N.P. Todaria. 2010. Plant diversity in two forest types along the disturbance gradient in Dewalgarh Watershed, Ggarhwal Himalaya. Current Science 98(7):938-943. 